\title{
Kontribusi Implementasi Pendidikan Karakter dan Lingkungan Sekolah terhadap Berpikir Kreatif serta Dampaknya pada Kompetensi Kejuruan
}

\author{
${ }^{1}$ Akhmad Fadli \\ ${ }^{2}$ Abdullah Isa \\ STAI Taruna Surabaya \\ 1fafifa05@gmail.com \\ 2abdullahiza013@gmail.com
}

\begin{abstract}
The research objective was to determine the direct contribution of the implementation of character education, school environment, and creative thinking to vocational competencies and to determine the indirect contribution of the implementation of character education and the school environment to creative thinking. The results showed (1) the implementation of character education directly and significantly contributed to the vocational competence of students; (2) the school environment directly and significantly contributes to the vocational competence of students; (3) creative thinking directly and significantly contributes to the vocational competence of students; (4) the implementation of character education indirectly contributes to vocational competence through creative thinking of students; and (5) the school environment does not contribute indirectly to vocational competence through students' creative thinking.
\end{abstract}

Keywords: character education, school environment, creative thinking, vocational competence

\section{Pendahuluan}

Dunia pendidikan diramaikan oleh Kebijakan Kementerian Pendidikan dan Kebudayaan yang tertuang dalam rencana strategis Kementerian Pendidikan Nasional Tahun 2010-2014 tentang pendidikan karakter. Berkembangnya perubahan kurikulum pendidikan yang mengedepankan perlunya membangun karakter bangsa dan juga membimbing peserta didik agar bersikap positif terhadap segala hal untuk kebaikan masa depan mereka sendiri. Hal ini didasarkan pada fakta dan persepsi masyarakat tentang menurunnya kualitas sikap dan moral anak-anak atau generasi muda. "Kebutuhan sekarang adalah kurikulum pendidikan yang berkarakter dalam arti kurikulum itu sendiri memiliki karakter, dan sekaligus diorientasikan bagi pembentukan karakter peserta didik" (Rohman, 2012:1).

Namun dalam pelaksanaannya, pendidikan karakter di sekolah saat ini dirasakan mendesak. Salah satu alasannya adalah konteks pendidikan formal di 
Indonesia lebih menitikberatkan pada pengembangan intelektual atau kognitif, sedangkan aspek soft skils atau nonakademik sebagai unsur utama pendidikan karakter belum diperhatikan secara optimal bahkan cenderung diabaikan (Zubaedi, 2012). Situasi tersebut sesuai dengan hasil pengamatan dan wawancara pada salah satu guru Jurusan Perkantoran SMK Kawung 2 Surabaya, dalam proses pembelajaran kecenderungan masih terfokus pada aspek kognitif peserta didik dan masih belum maksimal dalam pengembangan aspek afektif dan psikomotorik peserta didik. Logika yang ada, jika peserta didik hanya dilatih kognitifnya saja maka peserta didik akan kurang memiliki keterampilan dalam bidangnya.

Perubahan kondisi yang disebabkan oleh perubahan kurikulum yang dalam hal ini penyelenggaraan proses pendidikan di SMK, mengakibatkan adanya perubahan standar kompetensi yang mengintegrasikan nilainilai karakter di dalam kegiatan pembelajaran. Pendidikan karakter yang terintergrasi dalam proses pembelajaran yaitu melalui pengenalan nilai-nilai, kesadaran dan penginternalisasian nilai-nilai ke dalam tingkah laku peserta didik, baik dalam maupun di luar kelas pada semua mata pelajaran. Pada dasarnya kegiatan pembelajaran, selain untuk menjadikan peserta didik menguasai kompetensi (materi) yang ditargetkan, juga dirancang dan dilakukan untuk menjadikan peserta didik mengenal, menyadari/peduli, dan menginternalisasi nilai-nilai dan mengamalkannya dalam kehidupan sehingga tercermin perilaku yang baik.

Adapun tujuh belas Standar Kompetensi yang harus dicapai dalam Kompetensi Kejuruan Teknik Ototronik (1) membuat rangkaian elektronik terapan, (2) membuat sistem kontrol aplikatif dengan pemrograman berbasis micro-prosessor atau micro-controller, (3) memperbaiki system pengapian elektronik, (4) memperbaiki sistem injeksi elektronik, (5) memperbaiki sistem pengatur katup elektronik, (6) Memperbaiki sistem pengatur kecepatan otomatis, (7) memperbaiki sistem ABS, ASR/ETC dan ESP, (8) memperbaiki sistem transmisi otomatis dengan kontrol elektronik, (9) memperbaiki sistem suspensi aktif, (10) memperbaiki sistem automatic air conditioning, (11) memperbaiki car audio video, (12) memperbaiki sistem light-tronic,memperbaiki SRS (air-bag dan safety belt),memperbaiki sistem alarm, central-lock dan power windows, (15) memperbaiki sistem navigasi,memperbaiki sistem kontrol parkir, dan 
(16)memperbaiki sistem-sistem elektronik pada kendaraan.

Kompetensi merupakan kemampuan yang dimiliki oleh setiap individu yang digunakan untuk beradaptasi dengan berbagai jenis situasi kerja, di mana kompetensi dibutuhkan peserta didik dalam melakukan pekerjaan. Kompetensi tidak hanya diartikan memiliki keterampilan teknis tinggi, akan tetapi juga keterampilan menghadapi segala sesuatu. Kompetensi merupakan penjelasan mengenai sesuatu hal yang dilakukan seseorang di tempat kerja pada berbagai tingkatan tertentu, mengidentifikasi karakteristik pengetahuan dan keterampilan yang diperlukan individual yang memungkinkan menjalankan tugas dan tanggung jawab secara efektif sehinggga mencapai standar kualitas profesional dalam bekerja. Zwell (2000) mengungkap beberapa faktor yang dapat mempengaruhi kecakapan kompetensi seseorang (1) keyakinan dan nilai-nilai, (2) keterampilan, (3) pengalaman, (4) karakteristik kepribadian, (5) motivasi, (6) isu emosional, (7) kemampuan intelektual, dan (8) budaya organisasi. Menurut Santrock (2012), pendidikan karakter adalah pendekatan langsung untuk pendidikan moral yang melibatkan pengajaran moral dasar untuk para peserta didik agar mencegah mereka terlibat dalam perilaku amoral dan melakukan hal yang berbahaya bagi diri mereka sendiri maupun orang lain. Argumennya adalah bahwa perilaku seperti berbohong, mencuri, dan mencontek adalah salah dan bahwa peserta didik harus diajari tentang hal ini di sepanjang masa pendidikan mereka.

merupakan salah satu bagian yang turut berperan dalam proses pembelajaran. Lingkungan sekolah atau lingkungan belajar yang berpengaruh terhadap pengembangan pribadi dan prestasi peserta didik memiliki beberapa aspek yang meliputi, kondisi fisik sekolah, hubungan antara kepala sekolah, hubungan guru dan peserta didik, norma antara peserta didik, dan rasa kenyamanan dan keamanan peserta didik di sekolah.

Berdasarkan uraian di atas, dapat disimpulkan jika lulusan SMK mampu berpikir kreatif, mereka memiliki kompetensi yang baik pula sehingga mampu bersaing di dunia usaha maupun dunia industri. Jika mereka mampu bersaing, maka tidak lagi ada pengangguran yang berasal dari lulusan SMK. Hasil dari penelitian Prayitno (2007) menunjukkan bahwa ada perbedaan prestasi belajar pada kompetensi sistem AC di mana kelompok peserta didik yang memiliki 
tingkat berfikir kreatif tinggi prestasi belajarnya lebih baik dari kelompok peserta didik yang memiliki tingkat berfikir rendah, dengan rerata prestasi belajar peserta didik pada

kelompok tingkat berfikir kreatif tinggi, sedangkan rerata hasil belajar peserta didik pada kelompok tingkat berfikir kreatif rendah. Namun fakta yang terjadi di lapangan menunjukkan masih minimnya kreativitas peserta didik. Oleh karena itu, dianggap perlu untuk melakukan penelitian mengenai kontribusi implementasi pendidikan karakter dan lingkungan sekolah terhadap berpikir kreatif serta dampaknya pada kompetensi kejuruan.

Penelitian ini bertujuan untuk mengetahui kontribusi secara langsung implementasi pendidikan karakter, lingkungan sekolah, dan berpikir kreatif terhadap kompetensi kejuruan dan untuk mengetahui kontribusi secara tidak langsung implementasi pendidikan karakter dan lingkungan sekolah terhadap konpetensi kejuruan melalui kemampuan berpikir kreatif..

Penelitian dilakukan pada peserta didik di SMK Kawung 2 Surabaya yang telah mengimplementasikan pendidikan karakter dalam proses pembelajaran. Dalam pengambilan sampel, peneliti hanya mengambil kelas XI semester IV tahun ajaran 2010/2020 SMK Kawung 2 Surabaya pada standar kompetensi memperbaiki sistem injeksi elektronik kompetensi dasar mendiagnosis kerusakan pada sistem injeksi elektronik.

\section{Metode}

Rancangan penelitian menggunakan path analysis model persamaan struktural. Disebut model struktural yaitu apabila setiap variabel terikat/endogen secara unik keadaannya ditentukan oleh seperangkat variabel bebas/eksogen (Riduwan, 2011). Ruang lingkup variabel sebagai berikut: (1) variabel $\mathrm{X}_{1}$ merupakan implementasi pendidikan karakter dalam proses pembelajaran, (2) $\mathrm{X}_{2}$ lingkungan sekolah di SMK Kawung 2 Surabaya, (3) variabel Y merupakan berpikir kreatif peserta didik kelas XI semester IV SMK Kawung 2 Surabaya, dan (4) variabel $\mathrm{Z}$ merupakan kompetensi kejuruan pada standar kompetensi memperbaiki lembaga perkantoran peserta didik kelas XI semester IV Kompetensi perkantoran di SMK Kawung 2 Surabaya.

Populasi dalam penelitian ini adalah peserta didik kelas XI semester IV 
Kompetensi perkantoran di SMK Kawung 2 Surabaya dengan jumlah 129 peserta didik. Sampel yang diambil dalam penelitian sebesar 32\% atau 40 peserta didik, agar sampel yang diambil dapat mewakili jumlah populasi yang ada. Instrumen yang digunakan dalam penelitian adalah lembar observasi, angket, dan tes. Lembar observasi digunakan untuk untuk pengumpulan data variabel implementasi pendidikan karakter, angket digunakan untuk pengumpulan data variabel lingkungan sekolah, dan tes digunakan untuk mengukur kemampuan berpikir kreatif dan kompetensi kejuruan peserta didik.

Uji coba instrumen dalam penelitian ini adalah untuk mengetahui ketepatan/kevalidan instrumen dan ketetapan atau keajegan (reliabilitas) dari instrumen penelitian. Sasaran uji coba instrumen penelitian ini adalah dua dosen ahli, dan dua guru kompetensi Perkantoran. Instrumen penelitian ini diuji cobakan kepada peserta didik kelas XI semester IV Kompetensi Keahlian perkantoran SMK Kawung 2 Surabaya dengan jumlah 40 peserta didik dari 129 peserta didik yang ada. Instrumen dalam penelitian ini menggunakan validitas konstruk dan validitas isi, sedangkan validitas prediktif dilakukan sebagai prediktor bagi performansi di waktu yang akan datang pada instrumen tes kompetensi kejuruan. Reliabilitas instrumen diuji dengan Cronbach's alpha melalui bantuan SPSS 20.0 for windows. Suatu instrumen memiliki reliabel jika nilai cronbach's alpha lebih besar dari 0,6. Teknik koeefisien alpha dipilih karena jawaban pada item intrumen yang dikembangkan bersifat non dikotomis.

Analisis butir soal dilakukan (1) daya pembeda soal, dan (2) tingkat kesukaran soal. Daya pembeda soal dilakukan untuk mengetahui kemampuan suatu soal untuk membedakan antara peserta didik yang pamdai dengan peserta didik yang kurang pandai, dengan menetapkan kelompok atas dan kelompok bawah pada instrumen tes berpikir kreatif dan tes kompetensi kejuruan. Tingkat kesukaran soal dilakukan untuk mengetahui peluang untuk menjawab benar suatu soal pada tingkat kemampuan tertentu yang bisa dinyatakan dengan indeks. Semakin besar indeks tingkat kesukaran berarti soal tersebut semakin mudah pada tes berpikir kreatif dan tes kompetensi kejuruan.

Teknik analisis data yang digunakan yaitu teknik analisis statistik deskriptif dan teknik analisis statistik inferensial. Analisis statistik deskriptif digunakan untuk menganalisis data pada hasil observasi dan angket 
implementasi pendidikan karakter dan lingkungan sekolah setiap butir soal, pada lembar observasi dan angket digunakan formula persentase. Selanjutnya, dilakukan teknik analisis statistik inferensial yang bertujuan untuk menguji hipotesis kontribusi implementasi pendidikan karakter dan lingkungan sekolah terhadap berpikir kreatif peserta didik serta dampaknya terhadap kompetensi kejuruan melalui analisis korelasi dan analisis regresi linier baik secara langsung maupun tidak langsung. Penelitian ini dilakukan dengan menggunakan bantuan SPSS 20 for windows dengan menggunakan taraf signifikansi 0,05 (5\%). Selain itu juga untuk memenuhi dua asumsi dasar yaitu data harus berdistribusi normal dan linier. Data yang sudah terkumpul dilakukan uji normalitas dan uji linieritas terlebih dahulu dengan menggunakan bantuan SPSS 20 for windows dengan menggunakan taraf signifikansi 0,05 (5\%).

\section{Pembahasan}

\section{Kontribusi Secara Langsung Implementasi Pendidikan Karakter (X1) terhadap Kompetensi Kejuruan (Z).}

Temuan pertama menunjukkan bahwa terdapat kontribusi yang signifikan implementasi pendidikan karakter terhadap kompetensi kejuruan. Dalam penelitian ini ditemukan korelasi positif yang signifikan antara implementasi pendidikan karakter dengan kompetensi kejuruan sebesar 0.658 (sig<0.05). Hal ini berarti makin baik implementasi pendidikan karakter peserta didik, makin baik pencapaian kompetensi kejuruan. Variabel implementasi pendidikan karakter dapat menjelaskan makin tingginya kompetensi kejuruan sebesar $30.03 \%$. Hal tersebut dapat dijadikan suatu indikasi bahwa implementasi pendidikan karakter dapat dipakai sebagai prediktor kompetensi kejuruan peserta didik, atau dengan kata lain bahwa implementasi pendidikan karakter berhubungan secara signifikan terhadap kompetensi kejuruan peserta didik pada Kompetensi Keahlian Teknik Ototronik. Artinya, semakin baik implementasi pendidikan karakter peserta didik, maka kompetensi kejuruannya semakin meningkat.

Temuan penelitian sesuai dengan Shumaker \& Heckel (2007) bahwa karakter adalah kombinasi dari kualitas moral dimana seseorang dinilai secara terpisah dari kecerdasan dan bakatnya. Karakter harus dilaksanakan dengan 
tindakan atau perbuatan kebajikan. Selanjutnya, Lickona (1991) menjelaskan bahwa karakter yang tepat bagi pendidikan nilai yaitu karakter yang terdiri dari nilai operatif, nilai dalam tindakan. Karakter yang baik terdiri dari mengetahui hal yang baik, menginginkan hal yang baik dan melakukan hal yang baik dalam cara berpikir, kebiasaan dalam hati dan kebiasaan dalam tindakan. Berdasarkan hal tersebut mengisyaratkan bahwa implementasi pendidikan karakter pada peserta didik akan berdampak pada pencapaian kompetensi kejuruan peserta didik.

Zubaedi (2012) menyatakan bahwa, pendidikan karakter secara terperinci memiliki tujuan sebagai berikut: (1) mengembangkan potensi kalbu/nurani/ afektif peserta didik sebagai manusia dan warga negara yang memiliki nilai-nilai karakter bangsa, mengembangkan kebiasaan dan perilaku peserta didik yang terpuji dan sejalan dengan nilai-nilai universal dan tradisi budaya bangsa yang religius, menanamkan jiwa kepemimpinan dan tanggung jawab peserta didik sebagai generasi penerus bangsa, (4) mengembangkan kemampuan peserta didik menjadi manusia yang mandiri, kreatif, dan berwawasan kebangsaan, dan (5) mengembangkan lingkungan kehidupan sekolah sebagai lingkungan belajar yang aman, jujur, penuh kreativitas dan persahabatan, dan dengan rasa kebangsaan yang tinggi dan penuh kekuatan.

Karakteristik kepribadian seseorang khususnya pada peserta didik bukanlah merupakan sesuatu yang tidak dapat diubah karena perubahan tersebut juga ditunjang dengan adanya interaksi dengan orang lain dan pengaruh dari lingkungan sekitar. Oleh karena adanya nilai-nilai karakter yang diintegrasikan dalam kegiatan pembelajaran, maka dengan mudah peserta didik dilatih untuk selalu berpikir positif tentang dirinya, maupun terhadap orang lain. Jika tujuan dari pendidikan karakter dapat tercapai serta adanya keyakinan akan dirinya sendiri, maka dengan sendirinya peserta didik lebih aktif dan produktif dalam pencapaian kompetensi kejuruan yang ditekuninya. Berdasarkan paparan di atas, tampaknya hasil yang diperoleh dalam penelitian ini sesuai dengan paparan teori yang dipakai sebagai dasar untuk perumusan hipotesis, sehingga dugaan yang menyatakan bahwa ada kontribusi yang signifikan implementasi pendidikan karakter terhadap kompetensi kejuruan telah terbukti secara empirik dalam penelitian ini.

Hasil penelitian ini relevan dengan temuan Boggs (2010) menyajikan hasil yang sesuai dengan kategori di mana karakter berada dalam kurikulum yang 
implisit dan eksplisit. Tindakan yang luas (etos kerja dan motivasi untuk mengerjakan tugas sekolah), hormat (untuk figur pemimpin, konvensi budaya, dan rekan-rekan), dan kualitas pribadi (disiplin diri, tanggung jawab pribadi, ketekunan, manajemen waktu, dan kejujuran). Selanjutnya, penelitian Najib (2012) menemukan bahwa pendidikan karakter yang terdiri dari karakter disiplin, percaya diri, dan mandiri berpengaruh terhadap prestasi belajar. Berdasarkan hasil tersebut dapat disimpulkan bahwa pendidikan karakter disiplin, percaya diri, dan mandiri yang ditanamkan kepada peserta didik secara bersama- sama berperan di dalam meningkatkan prestasi belajar peserta didik. $\mathrm{R}_{\text {square }}$ sebesar 0,329/33\% yang berarti ada faktor lain sebesar $67 \%$ yang berpengaruh terhadap prestasi belajar.

Selain itu, temuan dalam penelitian ini menyimpulkan bahwa terdapat pengaruh implementasi pendidikan karakter yang signifikan terhadap kompetensi kejuruan. Oleh karena itu, perlu dilakukan upaya-upaya tertentu untuk meningkatkan kompetensi kejuruan antara lain: (1) perlu diberikan pemahaman dan pengertian kepada peserta didik tentang kemandirian dalam pemenuhan kebutuhan sendiri dengan upaya sendiri tanpa bantuan orang lain, (2) perlu ditanamkan sikap disiplin dalam menaati peraturan dalam kegiatan pembelajaran dan praktikum, dan (3) perlunya diberikan pemahaman akan pentingnya tanggung jawab dalam melaksanakan tugas dan kerja keras dalam mencapai prestasi.

\section{Kontribusi Secara Langsung Lingkungan Sekolah (X2) terhadap Kompetensi Kejuruan (Z)}

Temuan kedua menunjukkan bahwa lingkungan sekolah berkontribusi secara signifikan terhadap kompetensi kejuruan. Dalam penelitian ini ditemukan korelasi yang signifikan antara lingkungan sekolah dengan kompetensi kejuruan sebesar 0,318 (sig<0.05). Nilai korelasi yang diperoleh membuktikan adanya tingkat hubungan yang lemah antara lingkungan sekolah dan kompetensi kejuruan. Besarnya kontribusi lingkungan sekolah juga memperlihatkan bahwa lingkungan sekolah kurang memberikan pengaruh atau sumbangan terhadap pencapaian kompetensi kejuruan peserta didik karena hanya $12.11 \%$ variasi kompetensi kejuruan dapat dijelaskan oleh variasi dari lingkungan sekolah. Hal tersebut mengindikasikan bahwa kompetensi kejuruan belum tentu dapat tercapai dengan adanya lingkungan sekolah yang kondusif. 
Temuan ini mengungkapkan bahwa lingkungan sekolah bukan merupakan satu-satunya hal yang berpengaruh terhadap pengembangan pribadi dan prestasi peserta didik. Tingkat hubungan yang lemah tersebut kemungkinan terjadi karena pencapaian kompetensi kejuruan peserta didik tidak hanya ditunjang oleh lingkungan sekolah saja, akan tetapi ada faktor-faktor lain yang lebih dominan. Selanjutnya, dimungkinkan juga ada variabel lain yang mengontrol hubungan antara lingkungan sekolah dengan kompetensi kejuruan, misalnya keterampilan dan pengetahuan kejuruan, bakat, minat, maupun motivasi yang harus dimiliki peserta didik dalam usaha pencapaian kompetensi kejuruan. Walaupun demikian, lingkungan sekolah tetap memiliki kontribusi terhadap kompetensi kejuruan sehingga tetap diperlukan dalam proses pencapain kompetensi kejuruan. Sebagaimana dikemukakan Sumitro (dalam Murti, 2012) bahwa sekolah adalah lingkungan pendidikan yang mengembangkan \& meneruskan pendidikan anak menjadi warga negara yang cerdas, terampil dan bertingkah laku baik.

Selain itu, temuan penelitian juga mengungkap adanya faktor-faktor lain yang mempengaruhi kurang maksimalnya lingkungan sekolah terhadap kompetensi kejuran adalah masih kurang maksimalnya motivasi yang diberikan oleh guru dalam proses pembelajaran, peserta didik pasif dalam proses pembelajaran, peserta didik juga mudah terpengaruh oleh teman yang berbuat negatif di dalam kelas misalnya, bercanda dan tidak serius apabila guru menjelaskan materi pelajaran dan tidak menghiraukan guru saat menjelaskan materi pelajaran di dalam kelas. Oleh karena itu diperlukan upaya-upaya tertentu untuk meningkatkan kompetensi kejuruan antara lain: (1) memberikan pemahaman dengan menumbuh kembangkan rasa saling menghormati dan menghargai baik sesama peserta didik maupun dengan guru, (2) diperlukan manajemen sarana dan prasarana dan kondisi ruang belajar/praktik untuk menunjang kenyamanan peserta didik dalam kegiatan pembelajaran, dan (3) meningkatkan sumber belajar dan kreativitas serta keaktifan guru dalam proses pembelajaran.

\section{Kontribusi Secara Langsung Berpikir Kreatif (Y) terhadap Kompetensi Kejuruan (Z)}

Temuan ketiga menunjukkan terdapat kontribusi yang signifikan berpikir kreatif terhadap kompetensi kejuruan. Dalam penelitian ini ditemukan korelasi 
positif yang signifikan antara berpikir kreatif dengan kompetensi kejuruan sebesar 0.703 (sig<0.05). Nilai koefisien korelasi menunjukkan adanya hubungan yang kuat antara kedua variabel tersebut. Hal ini berarti makin kreatif peserta didik dalam berpikir, maka makin baik pencapaian kompetensi kejuruan peserta didik. Variabel berpikir kreatif dapat menjelaskan makin tingginya kompetensi kejuruan sebesar $24.60 \%$. Hal tersebut dapat dijadikan suatu indikasi bahwa berpikir kreatif dapat dipakai sebagai prediktor kompetensi kejuruan peserta didik, atau dengan kata lain bahwa berpikir kreatif berhubungan secara signifikan terhadap kompetensi kejuruan peserta didik pada Kompetensi Keahlian Teknik Ototronik. Artinya, semakin tinggi kemampuan berpikir kreatif peserta didik, maka kompetensi kejuruannya semakin meningkat.

Hasil penelitian sesuai dengan teori yang dikemukakan Munandar (Dewi, 2013) bahwa kreativitas adalah cara mengapresiasikan diri terhadap suatu masalah, dengan menggunakan berbagai cara yang datang secara spontanitas yang merupakan hasil dari pemikiran. Tingkat hubungan yang cukup kuat antara lingkungan sekolah dan kompetensi kejuruan dimungkinkan terjadi karena kreatif dalam berpikir tumbuh dari adanya rasa ingin tahu yang amat besar sehingga dapat memberikan stimulus kepada peserta didik dalam mencapai kompetensi kejuruan yang diharapkan. Menurut Cashdan \& Welsh (dalam Supriadi, 2010) menemukan bahwa, peserta didik yang tinggi kreativitasnya lebih mandiri, mengusahakan perubahan dalam lingkungannya, dan relasi interpersonalnya lebih terbuka dan aktif. Sebaliknya peserta didik yang rendah kreativitasnya lebih rendah otonominya dan kurang menonjolkan dirinya.

Temuan penelitian ini didukung hasil penelitian Prayitno (2007) bahwa ada perbedaan prestasi belajar pada kompetensi sistem AC di mana kelompok peserta didik yang memiliki tingkat berpikir kreatif tinggi prestasi belajarnya lebih baik dari kelompok peserta didik yang memiliki tingkat berpikir rendah, data penelitian juga menunjukkan rerata prestasi belajar peserta didik pada kelompok tingkat berpikir kreatif tinggi sebesar 78, dan 94, sedangkan rerata hasil belajar peserta didik pada kelompok tingkat berpikir kreatif rendah sebesar 76,83. Selanjutnya, berdasarkan hasil penelitian Widoyo (2012) yang menunjukkan bahwa prestasi belajar peserta didik yang berkemampuan berpikir kreatif tinggi belajar dengan pembelajaran ICT based guided inquiry lebih tinggi daripada prestasi belajar 
peserta didik yang mempunyai kemampuan berpikir kreatif tinggi belajar secara konvensional. Lebih lanjut, dari hasil penelitian diperkuat bahwa, masalah dimensional kreativitas dan intelegensi adalah masalah peranan kreativitas dan intelegensi dalam prestasi di sekolah (Munandar, 2009).

Temuan dalam penelitian ini menyimpulkan bahwa terdapat pengaruh berpikir kreatif yang signifikan terhadap kompetensi kejuruan. Dengan demikian, dapat diketahui bahwa kreatifnya peserta didik dalam berpikir turut berperan penting terhadap kompetensi kejuruan peserta didik. Kreativitas dalam berpikir merupakan langkah awal seseorang dalam mencapai keberhasilan. Apabila peserta didik percaya bahwa dirinya kreatif dan inovatif, maka peserta didik akan termotivasi untuk terus berpikir tentang hal-hal ataupun penemuan baru yang berbeda dalam melakukan sesuatu. Oleh karena, jika peserta didik memiliki kreativitas dalam berpikir, maka peserta didik akan mampu meningkatkan kecakapannya dalam proses pencapaian kompetensi baik dalam usaha kepekaan memecahkan masalah maupun dalam menciptakan karya baru.

Namun masih terdapat faktor-faktor yang mempengaruhi kurang maksimalnya keberhasilan peserta didik dalam berpikir kreatif terhadap kompetensi kejuruan. Karena itu, perlu dilakukan upaya- upaya tertentu untuk meningkatkan kemampuan berpikir kreatif peserta didik antara lain: (1) memberikan pelatihan kepada peserta didik dalam melatih kemampuan, kreativitas dalam pemecahan suatu masalah tertentu misalnya dalam mendiagnosis kerusakan sistem injeksi, dan (2) memberikan motivasi dan pelatihan dalam bidang teknik Ototronik untuk menciptakan karya karya baru sebagai upaya mengembangkan kreativitas dalam berpikir.

\section{Kontribusi Secara Tidak Langsung Implementasi Pendidikan Karakter (X1) terhadap} Kompetensi Kejuruan (Z) melalui Berpikir Kreatif (Y)

Temuan keempat diperoleh bahwa implementasi pendidikan karakter secara tidak langsung berkontribusi signifikan terhadap kompetensi kejuruan melalui berpikir kreatif. Hasil analisis tersebut menunjukkan bahwa implementasi pendidikan karakter mempengaruhi berpikir kreatif dan secara tidak langsung berdampak pada kompetensi kejuruan. Selanjutnya berdasarkan hasil perhitungan analisis jalur struktur, diketahui bahwa kontribusi 
secara tidak langsung implementasi pendidikan karakter terhadap kompetensi kejuruan melalui berpikir kreatif adalah sebesar $11.49 \%$.

Hasil penelitian tersebut mengindikasikan bahwa pembentukan karakter peserta didik melibatkan berbagai aspek dalam usaha pencapaian kompetensi kejuruan peserta didik, diantaranya aspek pengetahuan, perasaan dan tindakan, dimana pendidikan karakter merupakan upaya yang dirancang dan dilaksanakan secara sitematis untuk menanamkan nilai-nilai perilaku peserta didik yang terwujud dalam pikiran, sikap, perasaan dan perbuatan. Kemudian dengan adanya pendidikan karakter dapat membuat perubahan pada sikap, perilaku, keterampilan atau kemampuan peserta didik dalam bidang yang ditekuninya.

Lebih lanjut, hasil penelitian juga diperkuat teori Schwartz (dalam Samani, 2012) bahwa: (1) pendidikan karakter membantu peserta didik mencapai sukses baik di sekolah maupun dalam kehidupan, (2) pendidikan karakter membantu peserta didik siap merespon berbagai tantangan kehidupan,(3) pendidikan karakter membantu meningkatkan perilaku proporsional dan menurunkan sikap dan perilaku negatif peserta didik, (4) orang-orang (dalam hal ini seluruh warga sekolah) yang berkata bahwa mereka peduli terhadap nilai-nilai, ternyata memang lebih senang bertindak berlandaskan nilai-nilai tersebut, dan (5) pendidikan karakter menjadikan pengajaran berlangsung lebih mudah dan belajar berlangsung efisien. Pendidikan karakter dipahami sebagai upaya penanaman kecerdasan dalam berpikir, penghayatan dalam bentuk sikap, dan pengamalan dalam bentuk perilaku yang sesuai dengan nilai-nilai luhur yang menjadi jati dirinya, diwujudkan dalam interaksi dengan Tuhannya, diri sendiri, antarsesama, dan lingkungannya (Zubaedi, 2012).

Berdasarkan lembar observasi, implementasi pendidikan karakter di sekolah telah menunjukkan bahwa semua nilai karakter yang diinternalisasikan dalam pembelajaran antara lain yaitu, mandiri, disiplin, jujur, tanggung jawab, rasa ingin tahu, dan peduli lingkungan dengan baik, sehingga nilai-nilai karakter yang sudah tertanam mamberikan stimulus atau merangsang peserta didik dalam berpikir kreatif. Salah satu usaha dalam pencapaian kompetensi kejuruan melalui berpikir kreatif yaitu melalui implementasi pendidikan karakter. Pengendalian diri, saling menghargai dan menghormati antar sesama, gaya belajar dan 
kemadirian merupakan beberapa hal yang dapat menunjang peserta didik untuk berpikir kreatif. Dengan adanya pembentukan karakter yang baik, maka dapat membantu peserta didik untuk mengatur bagaimana seseorang akan bekerja sama dengan lingkungan dan orang lain. Selain itu, dapat meningkatkan perilaku yang baik dan dapat mencapai potensi akademik secara utuh, sehingga peserta didik dengan mudah mendapatkan pekerjaan dan mampu bersaing dalam dunia kerja.

\section{Kontribusi Secara Tidak Langsung Lingkungan Sekolah (X2) terhadap Kompetensi Kejuruan (Z) melalui Berpikir Kreatif (Y)}

Temuan kelima diperoleh bahwa lingkungan sekolah secara tidak langsung berkontribusi signifikan terhadap kompetensi kejuruan melalui berpikir kreatif. Hasil analisis korelasi menunjukkan bahwa terdapat hubungan yang signifikan lingkungan sekolah dengan kompetensi kejuruan melalui berpikir kreatif sebesar 0.028. Nilai tersebut mengindikasikan bahwa hubungan antarvariabel tersebut tergolong sangat rendah. Kemudian berdasarkan hasil pengujian analisis secara individual, lingkungan sekolah tidak berpengaruh secara signifikan terhadap berpikir kreatif. Selanjutnya berdasarkan hasil perhitungan analisis jalur struktur, diketahui bahwa kontribusi secara tidak langsung implementasi pendidikan karakter terhadap kompetensi kejuruan melalui berpikir kreatif adalah sebesar $0.07 \%$.

Hasil penelitian ini sangat berbeda dengan hasil penelitian Patoni (2012) yang menemukan bahwa, pengelolaan lingkungan belajar peserta didik dan kinerja guru sangat berpengaruh terhadap motivasi belajar peserta didik sebesar $15 \%$, dan juga tidak relevan dengan hasil penelitian Komalia (2012) bahwa, kualitas lingkungan sekolah dan motivasi kerja guru berpengaruh positif dan signifikan terhadap prestasi kerja guru. Hasil penelitian ini juga tidak sesuai dengan hasil yang dikemukakan oleh Beetlestone (2012), bahwa setiap kelas bisa memiliki etos yang kreatif, tetapi sekolah harus mendukungnya supaya pengembangan potensi anak- anak bisa dilakukan secara maksimal. Etos sekolah menunjukkan nilai-nilai kreativitasnya melalui: (1) pajangan karya imajinatif dan penuh warna, (2) lingkungan yang menstimulasi, dan (3) mendukung penyelesaian masalah dan pendekatan-pendekatan investigatif. Kelas terbuka dengan struktur yang tidak kaku dan memberikan perhatian individual, lebih memupuk 
pengembangan kreativitas anak dibandingkan dengan kelas tradisional. Ruang kelas memberi banyak rangsangan visual yang menarik. Adanya pusat sains, pusat membaca, atau pusat aktivitas lain memungkinkan anak bereksperimen dan menjajagi berbagai bidang (Munandar, 2009).

Berdasarkan hasil penelitian ini, ditemukan adanya perbedaan antara teori dengan fakta yang terjadi dilapangan, kemungkinan diakibatkan adanya faktorfaktor lain yang lebih dominan mempengaruhi tingkat berpikir kreatif dibandingkan dengan lingkungan sekolah. Berdasarkan angket yang mengukur lingkungan sekolah menunjukkan bahwa, kondisi fisik sekolah, lingkungan sosial yang ada di sekolah, dan lingkungan akademis di sekolah adalah sangat baik, namun kondisi tersebut masih belum memberikan stimulus atapun rangsangan kepada peserta didik untuk dapat berpikir kreatif. Kegiatan yang dilakukan baik di dalam kelas maupun di luar kelas menunjukkan bahwa kurangnya stimulus untuk mengeluarkan cara berpikir kreatif peserta didik.

Faktor-faktor yang mempengaruhi kurang maksimalnya lingkungan sekolah terhadap kompetensi kejuruan melalui berpikir kreatif adalah kurangaya pajangan karya-karya imajinatif peserta didik, proses pembelajaran yang kurang memberikan stimulan untuk peserta didik dapat berpikir kreatif, kurang menariknya visual ruangan kelas, dan penekanan dalam proses pembelajaran sebatas hafalan dan mencari jawaban yang benar terhadap soal-soal yang diberikan.

\section{Kesimpulan}

Berdasarkan hasil penelitian dan pembahasan, dapat diambil kesimpulan sebagai berikut: (1) implementasi pendidikan karakter secara langsung berkontribusi dan signifikan terhadap kompetensi kejuruan peserta didik Kompetensi Keahlian perkantoran di SMK Kawung 2 Surabaya.

Keahlian perkantoran SMK Kawung 2 Surabaya dengan nilai kontribusi sebesar $30.03 \%$, dengan demikian dapat disimpulkan bahwa semakin baik implementasi pendidikan karakter peserta didik dalam pembelajaran maka kompetensi kejuruan peserta didik akan semakin baik, (2) lingkungan sekolah di SMK Kawung 2 Surabaya secara langsung berkontribusi dan signifikan 
terhadap kompetensi kejuruan peserta didik Kompetensi Keahlian Perkantoran di SMK Kawung 2 Surabaya dengan nilai kontribusi sebesar $12.11 \%$, dengan demikian dapat disimpulkan bahwa semakin baik kondisi dari lingkungan sekolah dapat menbantu dalam peningkatan kompetensi kejuruan peserta didik, (3) berpikir kreatif secara langsung berkontribusi dan signifikan terhadap kompetensi kejuruan peserta didik Keahlian Perkantoran di SMK Kawung 2 Surabaya dengan nilai kontribusi sebesar 24.6\%, dengan demikian dapat disimpulkan bahwa semakin kreatif cara berpikir peserta didik maka kompetensi kejuruan peserta didik akan semakin baik, (4) implementasi pendidikan karakter berkontribusi secara tidak langsung terhadap kompetensi kejuruan melalui berpikir kreatif peserta didik Kompetensi Keahlian Perkantoran di SMK Kawung 2 Surabaya dengan nilai kontribusi sebesar $11.49 \%$, dengan demikian dapat disimpulkan bahwa semakin baik implementasi pendidikan karakter peserta didik akan membantu peserta didik dalam berpikir kreatif, sehingga kompetensi kejuruan juga semakin baik, dan (5) lingkungan sekolah di SMK Kawung 2 Surabaya tidak berkontribusi secara tidak langsung terhadap kompetensi kejuruan melalui berpikir kreatif peserta didik Kompetensi V dengan nilai kontribusi sebesar $0.07 \%$, dengan demikian dapat disimpulkan bahwa untuk meningkatkan kemampuan berpikir kreatif, lingkungan sekolah kurang memiliki peran, yang kemungkinan diakibatkan adanya faktor lain yang lebih dominan.

Berdasarkan simpulan di atas, disarankan (1) dilakukan upaya untuk meningkatkan implementasi pendidikan karakter bagi peserta didik dalam rangka meningkatkan kreativitas peserta didik dalam berpikir dan mencapai kompetensi kejuruannya, upaya- upaya ini dapat dilakukan dengan perancangan dan penginternalisasian nilai-nilai ke dalam tingkah laku peserta didik sehari-hari melalui proses pembelajaran, baik dalam maupun di luar kelas pada semua mata pelajaran; dan (2) di SMK Kawung 2 Surabaya untuk dapat mempertahankan kondisi lingkungan sekolah terutama lingkungan belajar yang kondusif bagi pengembangan berpikir kreatif peserta didik yang berorientasi pada tercapainya kompetensi peserta didik kelas XI semester IV Kompetensi Keahlian Keahlian Perkantoran di SMK Kawung 2 Surabaya . 


\section{Daftar pusataka}

Beetlestone, F. 1998. Creative Learning. Terjemahan Narulita Yusron. 2012. Bandung: Nusa Media.

Direktorat Pembinaan SMK. 2008. Petunjuk Teknis Pengembangan Kurikulum

Tingkat Satuan Pendidikan SMK/MAK. Jakarta: Depdiknas.

Ferguson, P.D \& Fraser, B.J. 1999. Changes in Learning Environment During the Transition from Primary to Secondary School. Journal Learning Environments Research, 1: 369-383. Netherlands: Kluwer Academic.

Hamalik, O. 2004. Proses Belajar Mengajar. Jakarta: Bumi Aksara.

Lickona, T. 1991. Education for character: How Our Schools Can Teach Respect and Responsibility. Terjemahan Juma Abdu Wamaungo. 2012. Jakarta: Bumi Aksara.

Najib, A. 2012. Pengaruh Pendidikan Karakter terhadap Prestasi Belajar Siswa Kelas XI IPS SMA Negeri 1 Lawang. Skripsi tidak diterbitkan. Malang: Universitas Negeri Malang.

Munandar, U. 2009. Pengembangan Kreativitas Anak Berbakat. Jakarta: PT Rineka Cipta.

Purwanto. 2011. Evaluasi Hasil Belajar. Yogyakarta:Pustaka Pelajar

Rohman, M. 2012. Kurikulum Berkarakter (Refleksi dan Proposal Solusi terhadap KBK dan KTSP). Jakarta: Prestasi Pustakarya.

Riduwan, Enas, \& Adun R. 2011. Cara Mudah Belajar SPSS Versi 17.0 dan Aplikasi Statistik Penelitian. Bandung: Alfabeta.

Samani, M. 2012. Konsep dan Model Pendidikan Karakter. Bandung: PT Remaja Rosdakarya.

Shumaker, D. M \& Heckel, R.V. 2007. Kids of Character: a Guide to Promoting Moral Development. United States of America: An Imprint of Greenwood Publishing Group. 